\title{
9 \\ SDSC at 50: Towards a New Golden Age
}

\author{
Brendan Taylor
}

It was an afternoon in mid-2011 and I was working on the second floor of the Menzies Library - a habit that I had developed as a Master's student at the Strategic and Defence Studies Centre (SDSC) in the late 1990s. I was compulsively checking my email - a less positive habit that I also acquired in recent years - when a note came through from the head of Centre, Hugh White, asking whether I was free for a chat over coffee. Spending time in conversation with Hugh is one of life's great pleasures, and so I swiftly obliged and made my way over to The Gods Cafe on the ground floor of the Hedley Bull Centre.

The content of our conversation took me by surprise. Hugh had recently announced to the staff of SDSC that he was stepping down as head of the Centre after a stellar seven-year tenure and he was now in the process of canvassing potential applicants for the top job. He thought I should throw my hat into the ring. I was naturally flattered, but swiftly declined any interest. It was a job, I said to Hugh, that would perhaps tempt me a decade from now, but that I felt was too early to take on at that juncture in my career. In truth, the shoes of Hugh and his four predecessors were formidable ones to fill - too large for a mere 39-year-old, I felt at the time. Hugh, in his characteristically gentlemanly way, graciously accepted that decision but encouraged me to think the possibility over. 
As with most major decisions in my academic career, I recounted this conversation to my mentor, Paul Dibb, who quickly indicated that I had an obligation to support Hugh's request. Out of respect to Paul, I thus informed Hugh that I would apply. To this day, I'm uncertain as to whether Hugh and Paul were in discussions on the next head of the Centre. Paul was certainly influential in attracting Hugh to the SDSC and I suspect that they probably had. Deep down, though, I still felt far from ready to take on such a nationally important and internationally prominent post, and my initial instinct was to go through the motions if I even made it to the interview stage.

As fate would have it, however, in the period immediately following these conversations with Hugh and Paul, I was in Singapore at a conference that was also being attended by former Chief of the Australian Defence Force and now SDSC visiting fellow Admiral Chris Barrie. Ever perceptive, Chris could sense my half-heartedness regarding the application and encouraged me to quickly think otherwise. He rightfully pointed out that poor performances in job selection processes are often remembered and that these can do terminal damage to one's career prospects over the longer term. I thus gave it my all at the September 2011 job interview and departmental seminar. The rest is history.

I still clearly remember the first time I walked the corridors of SDSC in February 1997 (when the Centre was located in what has since become the decidedly more trendy 'New Acton' on the outskirts of The Australian National University (ANU) campus) and my feeling of awe and slight intimidation on seeing the names of such giants in the field of Australian strategic and defence studies as Des Ball, Coral Bell, Paul Dibb and David Horner on the office doors. That feeling of inspiration and intimidation is one that never really goes away, especially when one walks past the pictures of the former heads of Centre that hang on the wall just outside my office today. It's difficult, in my own case anyway, not to feel like the 'odd one out'. Hence, if the 1990s constituted a period of 'difficult transition' for the Centre, as Dibb characterises it in his contribution to this volume, taking over from White as head of Centre in late 2011 was a transition that I found immensely difficult personally at such a relatively young age. Yet it was also a transition made easier by the support of those who had been most central to initiating it - Hugh, Paul and Chris - who made sure I had plenty of space to start making my own imprint on the Centre 
but who were also steadfast in their support and in their willingness to provide counsel when asked for it. I also sought the advice early on of my doctoral supervisor and another mentor, Des Ball, which as always was immensely helpful. Perhaps most importantly, it was also a transition made easier by having such a remarkably collegial team of colleagues. That collegiality is a theme to which I'll return in this chapter's conclusion.

White's headship was one which accomplished a great deal and which left the Centre in remarkably good shape. He managed to pull the SDSC out of some of its darkest financial days - at one point, from memory, we had run up a deficit of approximately $\$ 750,000$ - to the point where we were once again 'in the black'. White was centrally involved in the resurrection of the Graduate Studies in Strategy and Defence (GSSD) program in the 2000s, which sprung to life as a result of Ross Babbage's entrepreneurial flair and which then thrived under the directorship of Rob Ayson. White and Ayson were a formidable combination. Respected scholars in their own right, they were both passionate educators and the period working with them through the mid-2000s, along with Stephan Frühling, Ron Huisken and our wonderful team of administrators, was undoubtedly the most enjoyable of my career to date - although Stephan still reminds me how hard we worked and how much marking we had to do!

In the fluid organisational environment of the ANU, however, White correctly recognised that the Centre needed to expand beyond its historically steady state of six to eight academic staff members in order to survive as an independent academic unit. By 2011, the Centre had become part of the newly formed School of International, Political and Strategic Studies (or IPS), which was an amalgam of similarly sized and minded units intent on maintaining an independent identity and, more importantly, budgetary autonomy. The inaugural Director of the School, Professor Paul Hutchcroft, understood and supported this desire and gave life to it by introducing an ingenious 'federated' organisational structure within the new school. SDSC was fortunate to have in Paul Hutchcroft such a strong supporter, which has enabled and facilitated the remarkable growth of the Centre over the past half decade. Such strong support has continued and deepened under its current Director, Professor Michael Wesley, who rebranded the School in early 2015, naming it after one of SDSC's own — the late Coral Bell. 
The Centre has tripled in size over the past half decade, to the point where it is now home to more than 20 academic staff. In his contribution to this volume, Tom Millar marvelled during the early 1990s at the size of the SDSC oak that had sprung from the seed he planted in the mid1960s. If only he could see the Centre today!

In addition to the steady income provided by the GSSD program, the Centre's remarkable growth has come about as a result of the expansion of its activities in two key areas. The first of these is the SDSC Security Studies program at the undergraduate level, which has burgeoned beyond all expectations.

The idea of an undergraduate program in security studies was not altogether new. During the early 2000s, when Babbage was (re)establishing the GSSD, he worked closely with Ball and the then Director of the Faculty of Asian Studies Tony Milner to establish a parallel undergraduate program based at the Faculty, but which could over time serve as a direct feeder into its SDSC graduate counterpart. The qualification associated with this undergraduate program was the rather awkwardly named Bachelor of Security Analysis (AsiaPacific) - a title derived largely out of deference to colleagues across campus in the then Faculty of Arts and Social Sciences, who saw the new qualification as a potential competitor to their undergraduate offerings in the field of international relations.

Despite the new degree's institutional base in the Faculty of Asian Studies, SDSC continued to be centrally involved in its planning and delivery. SDSC staff frequently appeared as guest lecturers, while our doctoral students provided the bulk of the program's tutorial staff. Milner's successor, Kent Anderson, recognised this by the late 2000s and, both for the good of the program and as part of a restructuring of the Faculty into a reconstituted School of Culture, History and Language, he negotiated with White for the transfer of the program to SDSC. With this transfer, the degree was rebranded as the slightly more palatable 'Bachelor of Asia-Pacific Security', which continued to keep our colleagues across campus happy. In recent times, personnel changes and a shift in direction to a decidedly more quantitative methodological focus have eased pressures on that front. As such, it became possible for SDSC to re-brand its undergraduate program again in 2014 as an even more marketable 'Bachelor of International Security Studies'. 
A second transformative event occurred in 2011 when the Centre won a substantial 10-year contract to deliver a graduate program to approximately 200 mid-level officers at the Australian Command and Staff College (ACSC). The successful bid was spearheaded by Frühling and it is no exaggeration to say that, without his leadership and entrepreneurship in winning this bid, the SDSC may well have succumbed to the restructuring processes that were occurring at ANU at that time. Instead, the SDSC almost overnight came to be regarded as a 'jewel in the crown' of the University (to borrow terminology used on occasion by its Chancellor and longstanding supporter of the Centre, Gareth Evans).

The early days of delivering upon this contract were demanding to say the least. I'd received some early advice that the biggest challenge of all would be our dealings with the military. In reality, nothing could have been further from the truth. I had had minimal, but generally positive, prior dealings with the Australian Defence Force (ADF). Consistent with this, SDSC's engagement with the leadership of the ACSC and the larger Australian Defence College has been extremely smooth during the first five years of this contract and I continue to be struck by the professionalism of the staff and course members there.

Yet the volume of work that needed to be done in order to match those high standards was considerable for a still-relatively small Centre, much of it falling onto the shoulders of Frühling (who acted as the inaugural Director of the program) and his dedicated deputy, Garth Pratten. Sensing my concern about the effect of this increased workload on the Centre, White quietly reassured me that things would settle down once we got through the first year. As I'm sure Stephan and Garth will attest, that first year seemed a very long one and I subsequently ensured that they both received well-earned sabbaticals in its aftermath as some form of compensation for their herculean efforts.

The upside of both the ACSC contract and the burgeoning undergraduate program was that they allowed the Centre to triple in size and to bring on a number of key new appointments.

Foremost amongst these was Daniel Marston who, by competitive process, won the position of Professor in Military Studies and Principal of the ACSC program, which subsequently came to be known formally 
as the Military and Defence Studies Program (MDSP). Marston is an Oxford graduate and protégé of Bob O'Neill. I'd got to know him a little when he succeeded me as the Centre's Defence-funded postdoctoral fellow during the mid-2000s - a position that he held for a couple of years before returning to the United States. During his first stint at the Centre, Marston was a reserved, albeit pleasant figure, who kept mostly to himself.

His rise from postdoc to professor is perhaps one of the most rapid in history, but one thoroughly deserved based upon his stellar research record. His doctoral thesis, for instance, won the prestigious Templer Medal and his 2014 book, The Indian Army and the End of the Raj, was runner-up for the prize. Marston returned to the Centre a much more authoritative figure, whose direct approach had the effect of rubbing some up the wrong way, but which played extremely well in the military setting. His forthright manner notwithstanding, few would dispute the fact that he has managed to establish in the MDSP a genuinely world-class graduate program within an extremely short period of time. In particular, Marston's 'Art of War' program, wherein he takes a group of the 'best and brightest' from amongst course members in this program and puts them through a more rigorous and in-depth course of specialised study, has already attracted the attention of some of the world's leading staff colleges and universities.

Two other colleagues took on important leadership roles in the midst of this transition. Ben Schreer, a scholar of German extraction who was appointed to convene the Bachelor of Asia-Pacific Security, became the deputy head of Centre. White had opted not to appoint a deputy during his tenure as head, but it was a position that had traditionally existed within the Centre and that had been occupied by such luminaries as Ball (during $\mathrm{O}^{\prime} \mathrm{Neill}$ 's time as head) and Horner (during Dibb's tenure). With the Centre expanding rapidly and given my own relative lack of leadership experience, I figured I could use all the help I could get. Schreer's talents as an analyst were quickly recognised around the broader Canberra security community, however, and he understandably took up a good career opportunity at the Australian Strategic Policy Institute (ASPI), lasting little more than 12 months as deputy head of SDSC. Nevertheless, he made an important stabilising contribution during this difficult transition period. 
Peter Dean succeeded me as Director of Studies, a post that I had assumed following Ayson's departure in 2009. An historian by training, Dean joined the Centre before I assumed the headship as a replacement for Huisken, who had indicated his intention to retire. Dean came to the Centre from an associate deanship at the University of Notre Dame in Sydney. He was seeking to spend less time on administration and more on research, but his strong administrative pedigree was too tempting for me to resist and he graciously (if probably somewhat reluctantly) accepted the offer to become Director of Studies. Dean has thankfully been able to maintain an impressive trajectory during his time with the Centre, in addition to making an outstanding leadership contribution to the Centre's education programs. During his time as Director of Studies, numbers in the GSSD program rose to record levels and his administrative prowess was recognised elsewhere in the university, as reflected by his appointment as Associate Dean of the College of Asia and the Pacific in June 2015.

The trials of transition notwithstanding, late 2011 was an exciting time as we embarked upon the largest recruitment process in the Centre's history. The first round of job advertisements attracted a field of more than 100 candidates. From this field, we were able to recruit some outstanding new talent. I was especially pleased that we received an application from Amy King, a Rhodes scholar who was completing a doctorate on Sino-Japanese relations at Oxford under the supervision of Rosemary Foot. I'd been following King's work for some time but, evidently, so too had others and I realised that SDSC faced some stiff competition (even from within the ANU itself) were we to succeed in attracting her to the Centre. King had been working closely for a number of years with the hugely respected Peter Drysdale from the Crawford School. Our colleagues in the International Relations department were also recruiting at that time and showed interest in hiring her. Thankfully, the head of International Relations, Bill Tow quickly recognised how keen I was to recruit King and graciously gave me more space than others in the same position might have afforded. Indeed, some of the earlier contributions to this volume have highlighted the often tense historical relationship that has existed between SDSC and International Relations, but relations between our two units have been at their best ever in recent times and that is in large part due to Tow's collegiality and friendship, for which I am immensely grateful. 
Another new talent to emerge from the December 2011 recruitment round was Joanne Wallis, an Australian-born, recent University of Cambridge graduate. Wallis is an expert on the South Pacific, an area of obvious strategic importance in which the Centre had not been strong for some time - at least since the days that it counted Greg Fry and David Hegarty amongst its ranks. Wallis had already published in a couple of the leading scholarly journals and went on to convene the Bachelor of Asia-Pacific Security following Schreer's departure a role that she performed with distinction.

Andrew Carr, a young Australian foreign policy specialist who was competing his doctorate whilst also working at the Lowy Institute for International Policy, primarily on The Interpreter blog, also joined the ranks of SDSC out of this initial recruitment round. As noted later in this chapter, amongst his many other contributions Carr has been an immensely valuable addition to the Centre's outreach program, which he convened upon joining SDSC until the end of 2015 when he moved to run the Master's program.

Last, but certainly not least, a relatively long-time associate of the Centre, Jean Bou, who previously worked with Horner on the Official History of Australian Peacekeeping, also joined the Centre, where his primary role was to contribute his operational expertise to the newly established MDSP.

Notwithstanding these promising appointments, the Centre lacked scholars working on classical strategic studies, especially in the areas of strategic theory and concepts. Ayson's departure left a gap in this regard and the problem became more acute following Schreer's move to ASPI. With Ball due to retire, this left the Centre with Frülhing as the only specialist in this area, despite it being central to SDSC research and teaching. Specialists in this area proved to be in short supply and recruitment was more difficult than anticipated. We were fortunate in the end to find a recently minted doctorate in political science, Charles Miller, who had been working under the supervision of a leading scholar of strategic studies, Peter Feaver, at Duke University.

These appointments made the once top-heavy Centre appear a little light in terms of experience, especially with the looming retirements of a number of SDSC stalwarts such as Ball and Huisken. Joan Beaumont's request for an internal transfer within the university to SDSC thus came 
at an opportune time. I'd first met Beaumont when she was a visiting fellow with the Centre in the mid-2000s. She subsequently joined ANU as Dean of Education in the College of Arts and Social Sciences, and in that capacity I'd often admired her skill as an academic bureaucrat and enjoyed watching her in action at College Education Committee meetings. But Beaumont was also a well-regarded scholar in her own right who, like Dean, was eager to devote more time to research. I'd encountered Joan most recently as a member of the selection panel for the SDSC headship and it was perhaps in that capacity that her early explorations with White regarding a move to the Centre transpired.

The subsequent recruitment of Russell Glenn, who had spent much of the previous decade working at the RAND Corporation, and the conversion to continuing status of John Blaxland following Ball's retirement added further experience to an otherwise young staff. Even with these important additions, one of the concerns that had weighed most heavily on my mind for much of the past decade strategists have a naturally anxious disposition, it would seem - was how the Centre was going to survive the transition brought about by the retirement of the genuinely world-class cohort around which it had built much of its national and international reputation. I recall having a discussion on this subject with Ayson during the mid-2000s when we contemplated what the Centre would look like following the eventual retirement from academic life of the likes of Bell, Dibb, Ball, Huisken and Horner. Based upon his career pattern and trajectory prior to joining SDSC, I don't think many expected White to remain at the Centre as long as he has either - and we are immensely fortunate, of course, that he has chosen to do so.

Particularly in the context of this process of generational change, therefore, the recruitment of Evelyn Goh as the Centre's inaugural Shedden Professor in Strategic Policy Studies was critical. I'd known Goh for about a decade prior to her joining the SDSC, having first met at a workshop organised by Tow at Griffith University in the early 2000s, and I'd been a great admirer of her work ever since. A decade on, she was one of the world's leading scholars of Asian security. Her post at SDSC was funded by the Australian Department of Defence, who wanted to give more of a contemporary focus to the professorial position that it had been funding at the Centre for the better part of a decade. Goh fitted the bill perfectly and was the stand-out candidate from the field of applicants for the Shedden Chair. 
Goh's arrival added considerable weight to an expanding Centre that was beginning to gather momentum in terms of substantially increasing its research output. Particularly pleasing was the significant increase in the number of books by Centre staff that were being published by highly regarded university presses. Goh has particularly helped to build SDSC's research strength in Asia-Pacific Security, with China a growing area of expertise. This was strengthened in 2016 with the hiring of Bates Gill, formerly of the University of Sydney and a former Director of the Stockholm International Peace Research Institute (SIPRI), and Dr Nina Silove from Stanford University. The Centre's rate of success in applying for major grant funding was also on the rise. Blaxland, for instance, was the only non-American applicant to succeed in winning a prestigious Minerva grant from the US Department of Defense in 2014. Similarly, in collaboration with Gill, Goh was successful in winning a grant as part of the MacArthur Foundation Asia Security Initiative. Beaumont and Wallis each won prestigious Australian Research Council Discovery grants in the 2015 round.

The national and international recognition that is currently being afforded to research produced at the Centre is also notable. The writings of White are particularly worthy of mention in this regard, especially his 2012 book The China Choice, which built upon his earlier Quarterly Essay 'Power Shift'. White's work is now routinely cited in most of the leading contemporary analyses of Sino-American relations and it has defined the major foreign policy debate in Australia over how Canberra should position itself between a rising China and a United States that is (arguably) in decline. Likewise, Beaumont won the 2014 Prime Minister's Literary Award for Australian History for her highly acclaimed study of Australia during the First World War, Broken Nation: Australians in the Great War. Not to be outdone by a fellow historian, David Horner won the 2015 Prime Minister's Literary Award for Australian History for The Spy Catchers, which was the first volume in the Official History of ASIO series. He also in picked up the St Ermin's Hotel Intelligence Book of the Year for 2015. Yet few achievements could match the inclusion of Ball and White - such different and yet such hugely influential and important Australian strategic thinkers - on the Queen's Birthday Honours List in June 
2014. These were extremely special and fitting honours, although it couldn't help but reinforce my sense of inferiority, given that each of my predecessors had now had been awarded the Order of Australia!

The Centre's increasing profile owes a great deal to the outstanding job that Carr has done in leading its outreach program. Two particular areas are worthy of mention. The first is the Centre of Gravity policy papers, a series that has become the Centre's flagship publication and that Carr has been editing since it was launched in November 2013. The Centre previously published hugely successful (and important) SDSC Canberra Papers on Strategy and Defence and Working Papers. Partly for financial reasons and partly due also to the fact that the face of publishing was rapidly changing, White (correctly in my view) opted to abandon these earlier series.

The shorter-form Centre of Gravity series was designed to take their place. Carr and I also toyed with the idea of starting up a blog, but we ultimately felt that we would prefer an intellectually meatier product and that other Australian think tanks (such as ASPI and the Lowy Institute) were already successfully occupying that space. The purpose of the new series was to bring the best national and international minds to bear on the key strategic policy challenges facing Australia. Publication in the series is generally by invitation only and the series has thus far featured a range of world-class contributors that has included Tim Huxley, Robert Ross, Raja Mohan, Rory Medcalf, Geoffrey Till, Dennis Blair, Bob O'Neill, Bates Gill, Michael Green, Bilahari Kausikan, Brad Glosserman and Scott Snyder.

Another feature of SDSC outreach under Carr's leadership was his management of a popular program of public events. These have been held at the ANU and, typically in the case of book launches, at national institutions around Canberra including Parliament House, the Australian War Memorial and the National Museum of Australia. Carr has attracted a range of important and influential figures, including Defence secretaries (Dennis Richardson) and ministers (David Johnston), foreign ministers (Bob Carr), former and future prime ministers (John Howard and Malcolm Turnbull), and other public figures of note (Paul Kelly, Angus Houston, Angus Campbell, John Garnaut and Brendan Nelson, for instance), to speak at these events. $\mathrm{He}$ has also been able to attract sizeable audiences. Not since the days of the legendary SDSC conferences of the 1970s and 1980s, which 
O'Neill discusses in his chapter, has the Centre been able to boast audience numbers in the several hundreds at its events. Following the launch of the May 2013 Defence White Paper, Carr ran a public lecture featuring Barrie, Richard Brabin-Smith, Dibb and White that attracted over 300 attendees and left standing room only in the Great Hall of University House. Three years later, the Centre repeated the feat with another full house in the Great Hall to hear discussion of the 2016 Defence White Paper.

One of the aspects of the Centre's outreach that concerned me most when I assumed the headship was SDSC's relationship with Defence. Unlike White and Dibb, being a lifelong academic, I had never held any position in government, never mind the role of deputy secretary and author of a Defence white paper. Dibb and White were each generous with sharing their connections. There were those within the department, particularly Michael Shoebridge, the First Assistant Secretary from the Strategic Policy division, who were particularly open to exploring new avenues for engagement with SDSC in those first couple of years. Yet Defence has experienced a series of challenges as a result of internal restructuring and, in my view, its relationship with SDSC thus wasn't anywhere near meeting its full potential. Something seemed to click in early 2015, however, which led to a much greater level of engagement, including the Centre being allowed to fairly regularly deliver in-house roundtables and lectures on site for Defence employees - something that I had been lobbying for at least a couple of years prior. These events benefit significantly from the very evident support given to them by senior officials within Defence, including Tyson Sara, Chris Birrer and Scott Dewar, who attend on a regular basis. They are led largely by Goh in her capacity as Shedden Professor. While requiring a good deal of trust on Defence's part for which I am both grateful and respectful - they seem to be of benefit to both sides. For this reason, the relationship with Defence is certainly one that I hope continues to deepen in the years ahead.

Notwithstanding all the exciting things that have been happening at the Centre as a result of its increased size, growth did not come without its challenges. One of the consequences of winning the ACSC contract, for instance, was that it led to a situation where the Centre brought on a significant number of military historians due to the heavy operational focus of the MDSP. As Horner notes in his chapter, military history has long been an important element of the Centre's 
work. Yet, by 2013, following the intense period of recruitment, I noticed that almost half of the Centre's staff was made up of military historians. This was potentially problematic for two reasons. First, it was apparent that colleagues were increasingly speaking about the 'two sides' of the Centre - the historians and the political scientists. While there was no hint of animosity, it wasn't a healthy state of affairs as it set up a dynamic that could pull the Centre in conflicting directions. Secondly, word was getting back to me that some senior officials in the Australian public service were beginning to question the relevance of the Centre relative to other organisations with a more contemporary focus, such as ASPI and the Lowy Institute.

I find the comparison with think tanks puzzling, given that SDSC's mission is to contribute to public and policy debate by offering something different: rigorous, academic research that is accessible and relevant to policymakers. This mission is complementary to that provided by think tankers, who typically react to unfolding developments, often in a pithier manner than that used in academia. Nevertheless, it is a comparison that is often drawn and cannot be ignored.

In an attempt to bring a greater sense of coherence to a rapidly expanding SDSC, in early 2014 I initiated, with the blessing of my colleagues, a small group process to contemplate where the Centre ought optimally to be 5-10 years from now and to develop vision and mission statements for taking us there. I invited Barrie to lead the group, given his experience with running these types of exercises with organisations infinitely larger and more complex than SDSC. I also asked Marston and Goh to join. They are not only the 'next generation' of professors at the Centre, but they also represented well the 'two sides' of the Centre that seemed to be emerging. Bringing these two sides together would thus benefit from their leadership, with the addition of Chris' policy experience of course.

The exercise lasted for the better part of 12 months. We met on a monthly basis, often at national institutions around Canberra. We did quite a bit of preparatory reading in advance of our meetings, both about the history of the Centre and about strategic studies as a field of study. We engaged with each of the living former heads of Centre to seek their counsel and advice, including at least one very productive and enjoyable dinner with $\mathrm{O}^{\prime}$ Neill when he was in town - a dinner that sparked a number of spin-off projects. Most importantly, we reported 
back regularly to SDSC colleagues at staff meetings and, by December 2014, we were able to gain their agreement to use the following vision and mission to chart the Centre's course for the decade ahead:

\section{Our Mission}

The Strategic and Defence Studies Centre (SDSC) is Australia's largest body of scholars dedicated to the analysis of the use of armed force in its political context. As a leading international research institution specialising in strategy and defence, SDSC has a three-part mission:

- To provide 'real world'-focused strategic studies that are researchbased, research-led and world-class. Our primary expertise within the broad field of Strategic Studies consists of three related research clusters: Australian defence, military studies, and AsiaPacific security. Our scholarship in these areas is intended to be recognised internationally and of value to the Australian policy community;

- To prepare and educate the next generation of strategic leaders military, civilian and academic - in Australia and the Asia-Pacific region by providing world-class graduate and undergraduate programs in strategic and defence studies; and

- To contribute toward a better-informed standard of public debate in Australia and the Asia-Pacific region using high-quality outreach and commentary on issues pertaining to our core areas of expertise.

\section{Our Vision}

Founded in 1966, the Strategic and Defence Studies Centre is proud to be counted among the earliest generation of post-World War II research institutions dedicated to the analysis of the use of armed force in its political context. The Centre seeks to build upon our achievements over the past half-century, and to play a leading role in shaping international strategic studies, policies and debates. Within the next decade, SDSC aims to position itself as the leading universitybased institution for research, education, and outreach in strategic and defence issues in the Asia-Pacific region. In a fluid and fast-changing strategic milieu, we will invest in the strategic development of our research and teaching programmes in order to play a leading role in defining Strategic Studies for our age. Our goal is to shape the areas of scholarship and policymaking that will inform the leadership of the Asia-Pacific, and equip strategic planners and analysts to be bold and innovative in addressing the challenges of the future. 
Some might argue that, framed as such, the mission and vision of the Centre remains too broad. To borrow an analogy from debates regarding the structuring of military forces, a case can be made that the above equates to something akin to a 'balanced force' - one that contains a little bit of everything and thus avoids hard and unpopular choices, which is potentially detrimental to the extent that it spreads effort and resources too thinly. ${ }^{1}$

While there is something to be said for this line of argument, the history both of SDSC and of strategic studies more generally cautions against too narrow a focus. Such a centre, for instance, may not have been sufficiently nimble to respond to the transformational opportunity presented when the ACSC contract came up for tender in 2011. Similarly, a more broadly focused centre may have been better positioned to ride out the ending of the Cold War in the late 1980s and early 1990s. By the same token, a centre focusing only on Australian strategic and defence policy issues would likely not have made the same mark internationally as SDSC has to date, given the limited number of international avenues through which to publish work on issues related to Australia.

Spreading the focus across academic, public and policy debates, as well as across the national, regional and global, will remain a tricky balancing act for a centre such as SDSC. Yet it is one that remains critical to its future viability. The key to SDSC surviving and thriving lies in us remaining a sufficiently broad church within which all members of staff are contributing work of international standard in their chosen area of focus - whether that be publishing in leading, policy-relevant outlets or more traditional academic journals and university presses (or both). This presents challenges of communication as well, and towards that end in May 2016 I restarted the SDSC newsletters that $\mathrm{O}^{\prime}$ Neill in particular had used to successfully inform and promote the Centre's achievements.

The next half-decade will be critical to the future of the Centre and it is my hope that the vision and mission statements we have established will guide us through this period. The end date of the ACSC contract, five years from now, will be a critical turning point.

1 For further reading on this point see Hugh White, 'The New Defence White Paper: Why We Need it and What it Needs to Do', Perspectives, Apr. 2008. 
Ideally, the existing, good working relationship between the ADF and the SDSC will continue and the Centre will remain the ADF partner in the delivery of the MDSP for a long time to come. But sound strategic thinking plans for the worst-case scenario. As such, while continuing to maintain and to build upon the high standards that have been set during the first five years of this program, it is vital that the Centre diversify its income and activities to the point where it could maintain its current size even were the ACSC contract to conclude at the 10-year mark. The Centre's burgeoning Bachelor of International Security Studies program is a promising step towards establishing this certainty. The Centre is also in a position to do much more than it currently does with government and with the private sector, both nationally and internationally, should it so choose. And we must not lose sight of the continued importance of the Master's program as the Centre's most enduring educational offering. The key challenge in any such process of diversification, however, will be to maintain coherence and to continue to adhere to high standards across all areas of activity, especially in our research.

The next five years will also be critical in that the process of staff regeneration will increasingly call upon our early and mid-career SDSC colleagues to fill the big shoes of the past. Promising signs that the Centre, both individually and collectively, is working towards doing that include the work of colleagues such as Blaxland, Dean and Carr to develop strong media profiles, speaking with increasing authority on Australian defence issues. Frühling's appointment to the external expert panel for the 2016 Defence White Paper demonstrates the high regard in which he is held in government and the Australian public service. The Centre does, however, still need to raise its international profile, in particular through publication in the leading academic and policy journals in the field, including Survival, International Security, The Washington Quarterly, Foreign Affairs, and the Journal of Strategic Studies, to name just a few. In recent decades SDSC colleagues such as Ball, Bell, Dibb and O'Neill appeared frequently in such journals. The onus is now on their SDSC successors to do the same.

Maintaining a strong sense of collegiality will be equally important as the Centre navigates the next few years. While there have been tensions within the Centre over the past 50 years, these have tended to be the exception rather than the rule. Certainly one of the reasons why I have remained at the SDSC for almost 15 years and why the 
Centre itself has been so successful is due to the fact that it is such a pleasant, supportive place to work. Such is a rarity in academic circles and is a special characteristic of the Centre that should never be taken for granted.

In the final analysis, the Centre is in a position to thrive over the next decade and beyond. As Dibb's contribution to this volume illustrates all too well, one of the great challenges facing a Centre such as ours is that our fate is tied all too closely to the prevailing strategic environment of the time. SDSC was born, for instance, during the mid-1960s. This period was often referred to as the 'golden age' of strategic studies due to the significant and substantial work being done to develop a more scientific approach to the strategic challenges of the time, particularly the advent and evolution of nuclear weapons. Equally, the end of the Cold War in the late 1980s and early 1990s led to debates over whether strategic studies should even survive. As Dibb notes, this was a dark and dangerous period for the Centre.

By contrast, few would question the relevance of strategy and strategic studies in today's world, where great power competition is on the rise in Asia and where conflict is again breaking out in the Middle East and even in Europe. Some Australian policy elites claim that, as a result, Canberra currently faces its most demanding set of strategic circumstances in our country's relatively short history. As a consequence, a new golden age of strategic studies could well be upon us. As it has done admirably throughout its impressive 50-year history, it is up to SDSC to grab this opportunity with both hands. 
This text is taken from A National Asset: 50 Years of the Strategic and Defence Studies Centre, edited by Desmond Ball and Andrew Carr, published 2016 by ANU Press, The Australian National University,

Canberra, Australia. 